\title{
PENGGUNAAN SISTEM PENGGAJIAN KARYAWAN DENGAN APLIKASI NETBEANS IDE 8.0.2 BERBASIS SQL SERVER (STUDI KASUS PADA PT. REJEKI AGUNG MANDIRI - KLATEN)
}

\author{
Drajat Armono \\ Universitas Islam Indonesia \\ e-mail : drajatarmono@gmail.com \\ Lasri D Kurniati \\ Universitas Islam Indonesia \\ Niar Nisa Nastiti A \\ Universitas Gadjah Mada
}

\begin{abstract}
This study aims to determine the payroll system apllied to the agency. As well, this research also aims to determine the strengths and weaknesses of the system being run. In the payroll process, it was known that these agencies previously still used a manual system, so the payroll process took longer and the results obtained were prone to errors. However, along with the development of technology, the company changed the manual system to use the NetBeans IDE 8.0.2 server application system. The payroll system is designed by the company owner which aims to facilitate the finance department in the payroll process. Using the payroll system is faster and doesn't take longer, and the results in the calculation are clearer and more accurate.
\end{abstract}

\begin{abstract}
ABSTRAK
Penelitian ini bertujuan untuk mengamati penggunaan sistem penggajian yang diterapkan pada instansi tersebut. Penelitian ini juga bertujuan untuk mengetahui kelebihan dan kelemahan yang terdapat dalam sistem yang dijalankan. Dalam proses penggajian diketahui pada instansi tersebut sebelumnya masih menggunakan sistem manual, sehingga proses penggajian memakan waktu yang lebih lama dan hasil yang didapatkan rentan terjadi kesalahan. Namun, seiring dengan perkembangan teknologi, perusahaan mengubah sistem manual menjadi menggunakan sistem aplikasi NetBeans IDE 8.0.2 SQL server. Sistem penggajian tersebut dirancang oleh pemilik perusahaan yang bertujuan untuk memudahkan bagian keuangan dalam proses penggajian. Dengan menggunakan sistem penggajian tersebut ternyata menjadikan prosesnya lebih cepat dan tidak memakan waktu lebih lama dibanding penggunaan sistem manual, serta hasil dalam perhitungannya lebih jelas dan akurat.
\end{abstract}

Kata Kunci : Sistem, Penggajian, Aplikasi, Waktu.

\section{PENDAHULUAN}

Dalam permasalahan gaji perusahaan ini sebelumnya masih menggunakan sistem manual, yaitu perhitungan gaji setiap karyawannya sebagian besar masih menggunakan metode tulis tangan, sehingga proses yang terjadi memakan waktu yang lama dan rentan terjadi kesalahan. Namun, seiring dengan perkembangan teknologi yang sangat pesat untuk memudahkan dalam proses penggajian, perusahaan mengubah sistem manual menjadi 


\section{Buletin Ekonomi}

menggunakan sistem aplikasi NetBeans IDE 8.0.2 berbasis SQL Server. Sistem tersebut dirancang oleh pemilik PT. Rejeki Agung Mandiri yang bertujuan untuk membantu pihak perusahaan dalam hal layanan operasional. Serta untuk memudahkan dalam proses gaji lebih cepat, tepat dan tidak memakan waktu lebih lama, dan dalam menyampaikan informasi gaji lebih jelas dan akurat.

Tanpa adanya sistem penggajian yang jelas dan akurat, dapat menyebabkan terjadinya penyelewengan dan penyimpangan dalam melaksanakan tanggung jawab masing-masing. Oleh karena itu perusahaan harus memisahkan tugas antara bagian penggajian dengan bagian yang lain untuk menghindari adanya salah perhitungan serta keperluan lain yang tercampur dan tidak terklasifikasi secara memadai. Sehingga dalam perusahaan membutuhkan suatu sistem penggajian yang tersusun rapi dan teratur agar dapat lebih memudahkan bagi bagian penggajian dalam menetapkan gaji karyawan. Selain itu, sistem penggajian yang jelas juga dapat menyediakan data-data yang lebih akurat untuk mengambil keputusan. Sistem penggajian dibagi menjadi beberapa pokok penting yaitu presensi, catatan lembur, pinjaman, dan prosedur yang membentuk suatu sistem penggajian. Apabila dalam suatu sistem penggajian dilakukan sesuai dengan prosedur yang telah ditetapkan, maka akan tercapai suatu kedisiplinan kerja pada bagian yang terkait, sehingga sangat jelas terlihat bahwa sistem penggajian berperan sangat penting bagi perusahaan dan karyawan itu sendiri.

Berdasar pemikiran di atas yang sudah dijelaskan karena pentingnya suatu sistem penggajian dalam sebuah perusahaan penulis mengambil judul "Penggunaan Sistem Penggajian Karyawan dengan Aplikasi NetBeans IDE 8.0.2 Berbasis SQL Server (Studi kasus pada PT. Rejeki Agung Mandiri - Klaten)".

Dalam beberapa literatur disebutkan pengertian sistem dalam beberapa pengertian. Pada tulisan ini penulis menggunakan definisi operasional bahwa sistem merupakan suatu rangkaian dua atau lebih komponen yang saling terkait dan berinteraksi untuk mencapai tujuan, yang terdiri atas suatu subsistem untuk mendukung sistem yang lebih besar (Romney \& Steinbart, 2017).

Di sisi lain, dalam sebuah sistem mengandung unsur adanya informasi yang menjadi output-nya. Secara definisi informasi adalah sekumpulan data yang telah diproses dan diolah menjadi sebuah bentuk yang mempunyai makna, yang digunakan untuk memberikan hasil dari data yang telah diproses dan dikelola tersebut dalam pengambilan keputusan.

Dari kedua definisi operasional tersebut maka dapat didefinisikan bahwa sistem informasi adalah metode yang diorganisasi untuk mengumpulkan, memasukkan, mengolah serta menyimpan data, dan cara-cara yang diorganisasi untuk menyimpan, mengolah, mengendalikan, dan melaporkan informasi yang sedemikian rupa sehingga sebuah organisasi dapat mencapai tujuan yang telah ditetapkan. (Krismiaji, 2015). Sedangkan menurut Rivai (2009) gaji adalah balas jasa dalam bentuk uang yang diterima karyawan sebagai konsekuensi dari kedudukan sebagai karyawan yang memberikan sumbangan dan pikiran dalam mencapai tujuan perusahaan. Siklus manajemen sumber daya manusia/penggajian merupakan suatu rangkaian kegiatan atau aktivitas bisnis yang terdapat dalam perusahaan dan pengoperasian pengolahan data yang terkait secara terus-menerus dan efektif yang berhubungan dengan pengelolaan terkait kemampuan karyawan (Romney \& Steinbart, 2017).

\section{METODE}

Flowchart/bagan alir merupakan suatu teknik analitis yang digunakan pada seperangkat simbol standar untuk menjelaskan gambar secara ringkas, jelas dan logis dalam beberapa aspek dari sistem informasi (Romney \& Steinbart, 2017). 


\section{Buletin Ekonomi}

Tabel 2.1 Simbol untuk Pembuatan Bagan Alir (Flowchart)

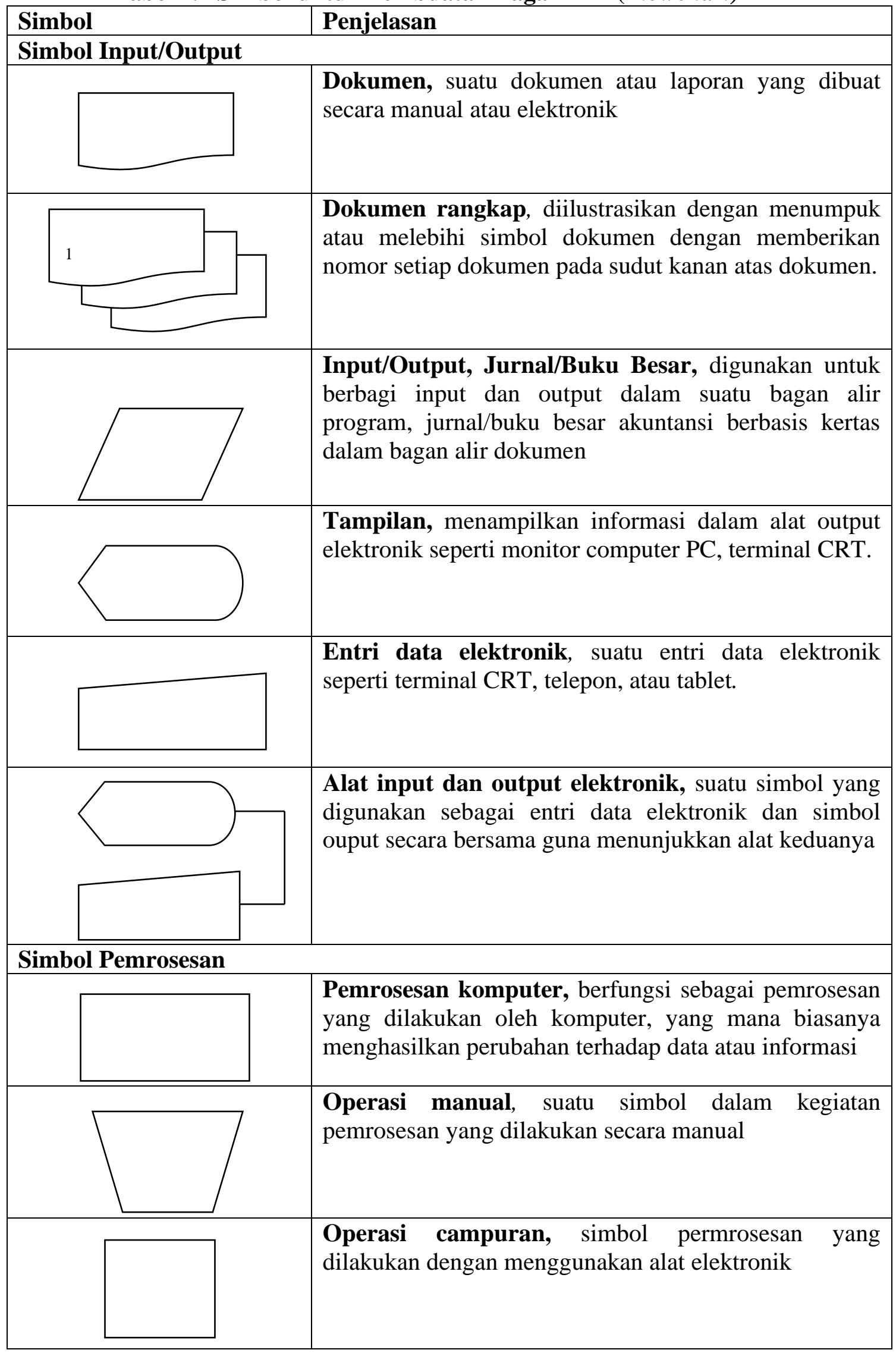




\section{Buletin Ekonomi}

\begin{tabular}{|c|c|}
\hline & $\begin{array}{l}\text { Operasi pemasukan data off-line, kegiatan yang } \\
\text { dilakukan menggunakan suatu alat pemasukan data off- } \\
\text { line (mengentri data ke disket, register kas) }\end{array}$ \\
\hline \multicolumn{2}{|l|}{ Simbol Penyimpanan } \\
\hline & $\begin{array}{l}\text { Database, data disimpan dalam database secara } \\
\text { permanen yang digunakan untuk menyimbolkan file } \\
\text { induk }\end{array}$ \\
\hline & Pita magnetik, data disimpan dalam pita magnetik \\
\hline & $\begin{array}{l}\text { Penyimpanan on-line, suatu data yang disimpan } \\
\text { sementara dalam file online ke dalam direct access } \\
\text { seperti disket }\end{array}$ \\
\hline & $\begin{array}{l}\text { Arsip/file dokumen kertas, digunakan untuk } \\
\text { mengarsip data dengan terdapat huruf didalamnya } \\
\text { untuk mengindikasikan file urutan pemesanan, } \mathrm{N}= \\
\text { secara numerik/nomor urut, } \mathrm{A}=\text { secara alfabet/abjad, D } \\
=\text { berdasar tanggal }\end{array}$ \\
\hline \multicolumn{2}{|c|}{ Simbol Arus dan Lain-lain } \\
\hline & $\begin{array}{l}\text { Arus dokumen atau pemrosesan, arah arus } \\
\text { pemrosesan atau dokumen yang mana arus normalnya } \\
\text { ke kanan dan ke bawah }\end{array}$ \\
\hline & $\begin{array}{l}\text { Hubungan komunikasi, transisi data dari suatu lokasi } \\
\text { ke lokasi lainya dengan menggunakan garis komunikasi }\end{array}$ \\
\hline & $\begin{array}{l}\text { Konektor dalam halaman, digunakan untuk } \\
\text { meghubungkan arus pemrosesan dalam halaman yang } \\
\text { sama dan untuk menghindari terlalu banyak anak panah } \\
\text { melintang pada halaman }\end{array}$ \\
\hline & $\begin{array}{l}\text { Konektor luar halaman, digunakan untuk menandai } \\
\text { arus pemrosesan data di luar halaman atau ke dalam } \\
\text { halaman yang berbeda }\end{array}$ \\
\hline
\end{tabular}




\section{Buletin Ekonomi}

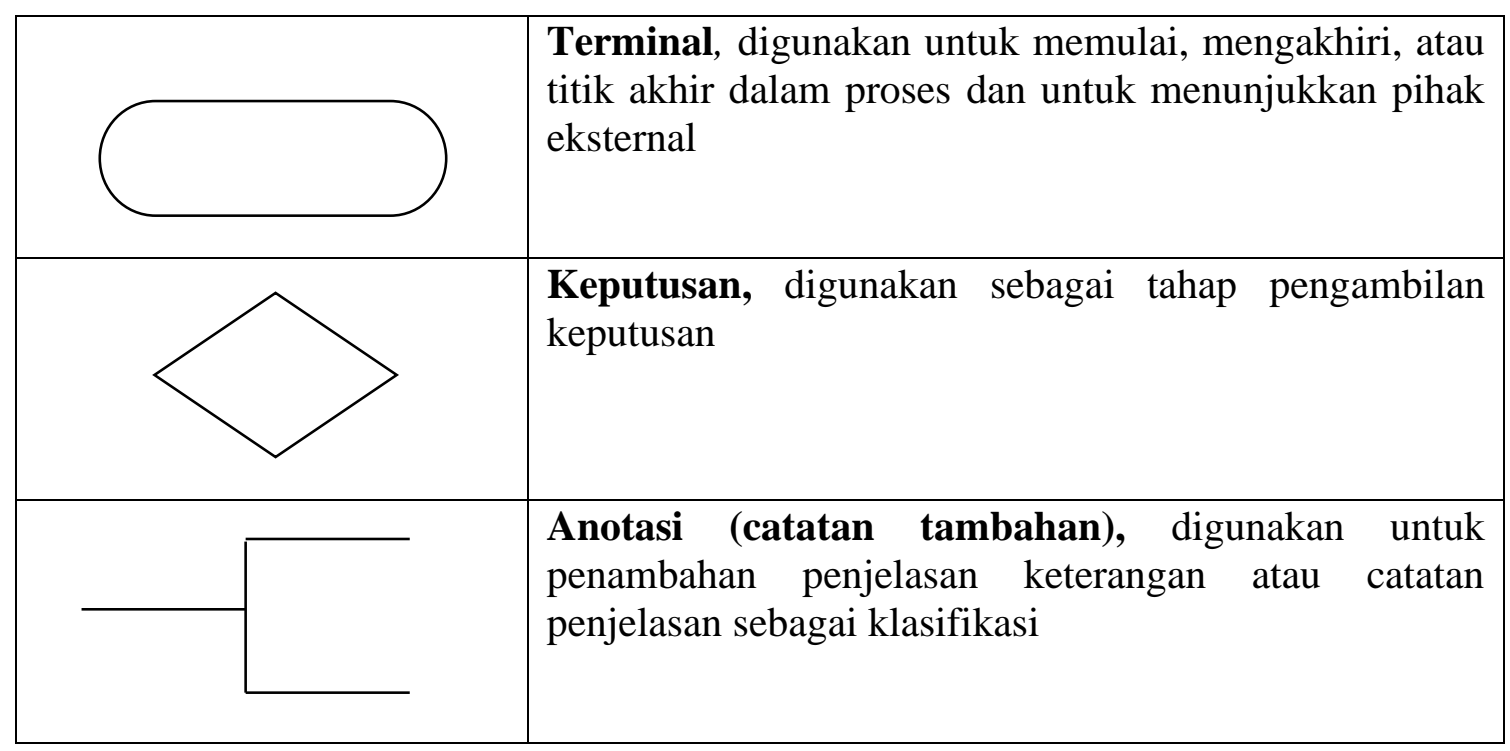

Sumber: Marshall B.Romney, Paul John Steinbart (2017)

Dalam artikel ini penulis menggunakan jenis data sekunder yang bersifat deskriptif kualitatif selama satu bulan Januari 2020, yang diperoleh dari PT. Rejeki Agung MandiriKlaten berupa data sistem penggajian. Data yang digunakan dalam penulisan ini adalah proses penggajian menggunakan sistem manual dan sistem aplikasi NetBeans IDE 8.0.2 berbasis $S Q L$ Server. Pengumpulan informasi data melalui bendahara bagian keuangan pada instansi tersebut.

\section{ANALISIS DAN PEMBAHASAN}

Proses Penggajian menggunakan sistem manual. Berikut gambaran alur proses (flowchart) dari penggajian menggunakan sistem manual pada PT. Rejeki Agung Mandiri: 


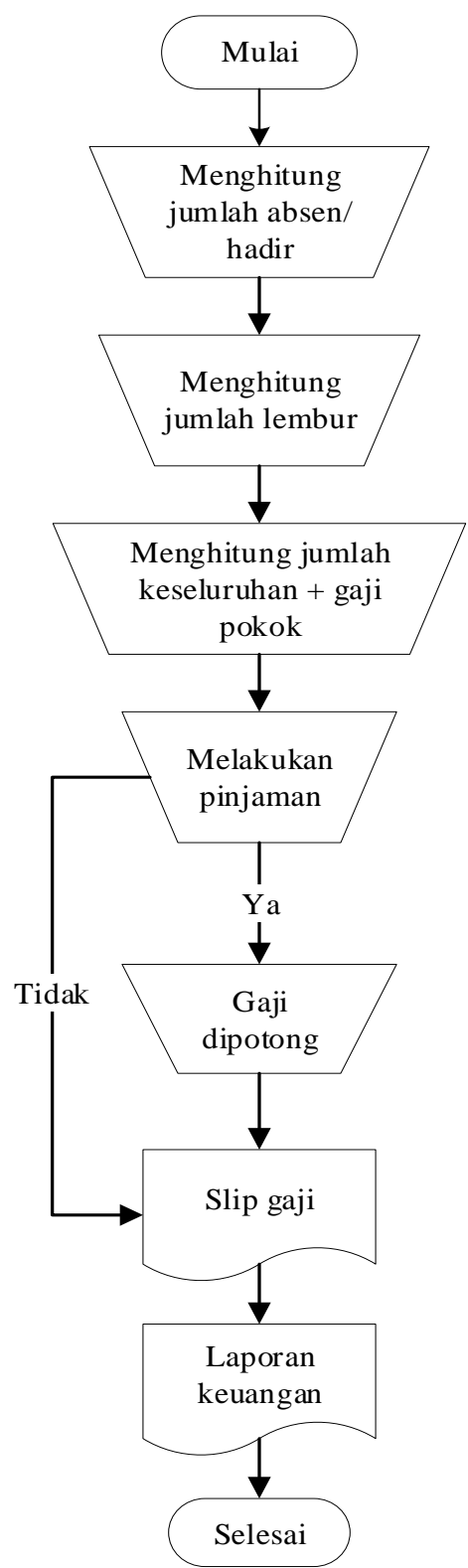

Gambar 4.1. Proses Penggajian pada PT. Rejeki Agung Mandiri (secara manual)

Penjelasan flowchart penggajian sistem manual:

1. Mulai

2. Staff/ admin keuangan terlebih dulu akan melakukan pengecekan data kehadiran karyawan, kemudian akan menghitung jumlah kehadiran karyawan

3. Setelah menghitung jumlah kehadiran karyawan, staff/admin keuangan akan menghitung jumlah lembur sesuai dengan jadwal lembur karyawan

4. Menghitung jumlah keseluruhan (jumlah kehadiran + jumlah lembur) ditambah gaji pokok sebulan karyawan

5. Selanjutnya apabila karyawan melakukan pinjaman maka jumlah keseluruhan gaji dipotong sesuai dengan nilai besaran yang dipinjam atau dicicil secara bertahap Namun, apabila karyawan tidak melakukan pinjaman maka staff akan langsung mengeluarkan slip gaji

6. Setelah pengeluaran slip gaji staff/bagian keuangan akan membuat laporan penggajian bulanan 


\section{Buletin Ekonomi}

7. Selesai.

Proses Penggajian menggunakan Sistem Aplikasi NetBeans IDE 8.0.2 berbasis SQL Server

Berikut bagan alur (flowchart) proses penggajian menggunakan sistem aplikasi NetBeans IDE 8.0.2 berbasis SQL sever pada PT. Rejeki Agung Mandiri:

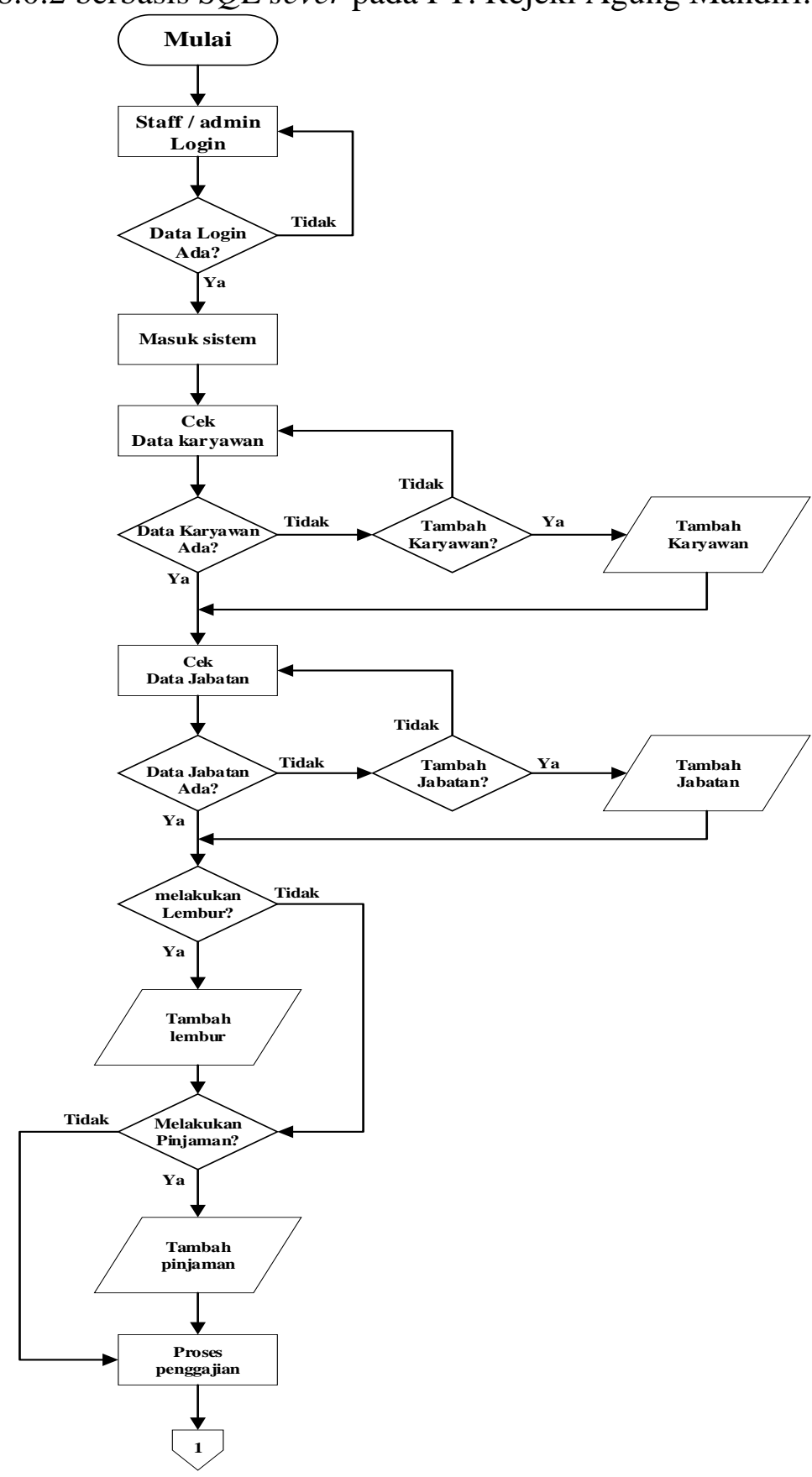




\section{Buletin Ekonomi}

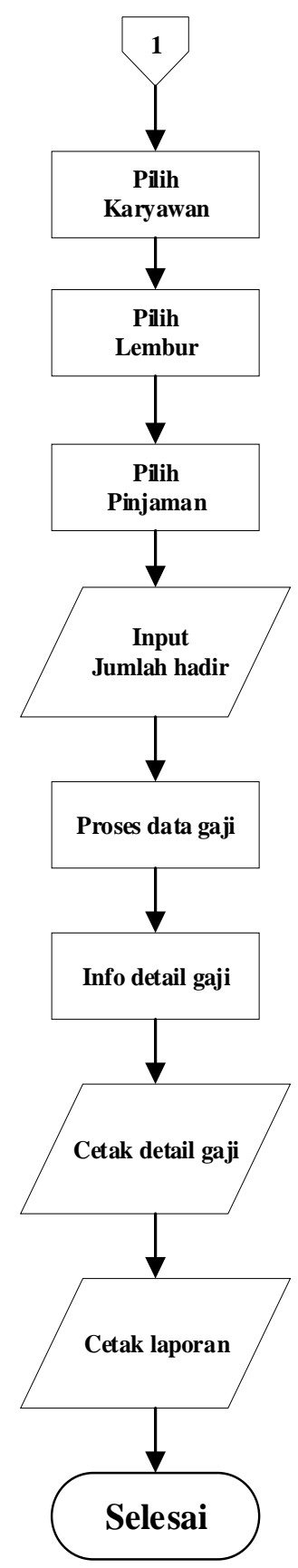

Gambar 4.2. Proses Penggajian PT. Rejeki Agung Mandiri (sistem aplikasi NetBeans IDE 8.0.2 berbasis SQL server)

Penjelasan flowchart sistem penggajian:

1. Mulai

2. Staff atau admin keuangan login terlebih dahulu, dengan syarat staff atau admin telah terdaftar dalam database

3. Apabila login telah berhasil, staff/admin keuangan berhasil masuk ke sistem

4. Sebelumnya admin terlebih dulu harus mengecek apakah data karyawan dan data jabatan sudah semua terdata secara lengkap. Apabila belum terdata, admin dapat menambahkan melalui halaman karyawan. Namun, yang dapat menambahkan hanya admin karena yang memiliki hak akses penuh untuk mengedit data karyawan dan jabatan hanyalah admin. 


\section{Buletin Ekonomi}

5. Jika ada karyawan yang melakukan lembur sesuai dengan jadwal maka operator sistem akan menginput lembur

6. Selanjutnya operator menginputkan pinjaman jika ada karyawan yang melakukan pinjaman

7. Dalam proses penggajian yang dilakukan, operator sistem hanya perlu menginputkan jumlah hadir karyawan untuk melakukan proses perhitungan gaji, karena aspek yang lain akan muncul secara otomatis melalui database. Namun, sebelum melakukan proses penggajian tersebut admin akan melakukan penggecekan data kehadiran karyawan

8. Setelah perhitungan gaji selesai, terdapat informasi gaji

9. Operator dapat mencetak slip gaji dan mencetak laporan penggajian secara otomatis tanpa harus membuat sendiri seperti menggunakan sistem manual sebelumnya.

10. Selesai

Berikut ini merupakan tampilan sistem aplikasi NetBeans IDE 8.0.2 berbasis $S Q L$ server dalam proses penggajian pada PT. Rejeki Agung Mandiri:

1. Halaman Utama Aplikasi

Halaman utama adalah halaman yang beisi menu-menu dalam aplikasi yang pertama kali pada saat program dijalankan. Namun, semua tombol tidak aktif kecuali tombol login, tombol-tombol menu akan aktif saat operator login. Halaman awal aplikasi dapat dilihat pada Gambar 4.3

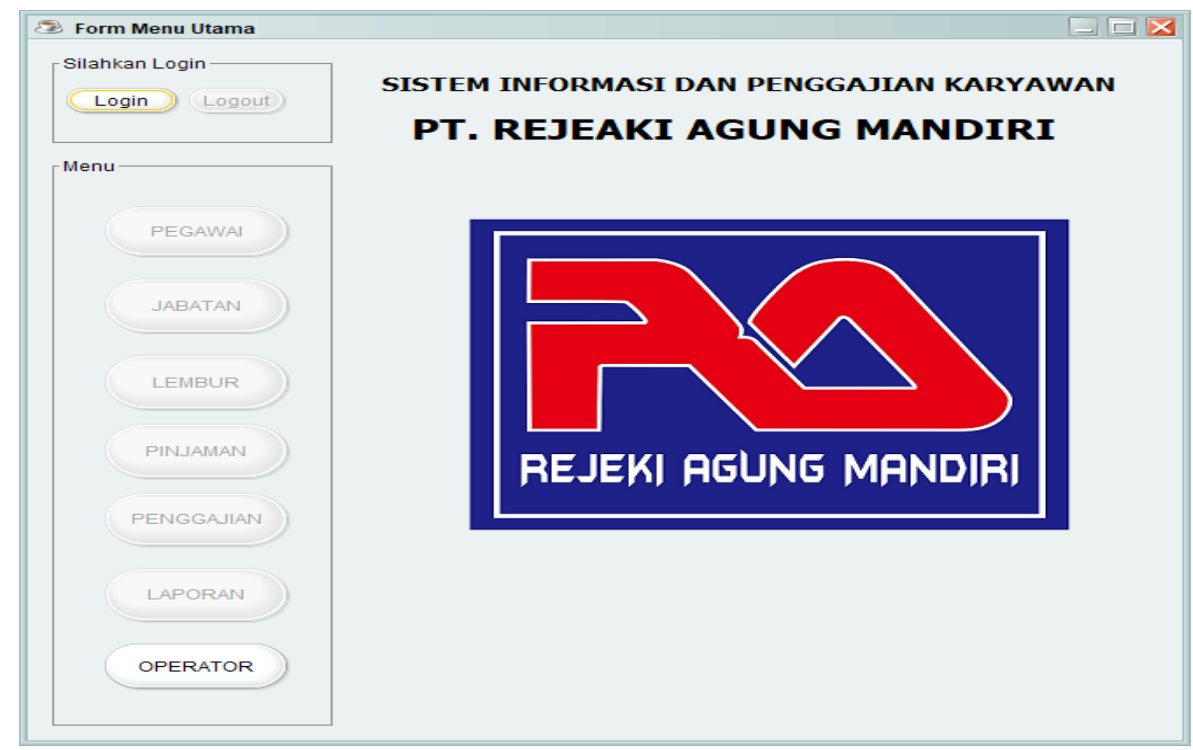

Gambar 4.3. Halaman Utama Sistem Aplikasi yang belum aktif

2. Halaman Login

Untuk masuk ke dalam sistem tekan tombol login, maka menu login akan muncul secara otomatis. Namun, kewenangan untuk menu login hanya admin terdaftar yang dapat masuk dan menggunakan program penggajian ini. Hal tersebut dapat dilihat pada Gambar 4.4 


\section{Buletin Ekonomi}

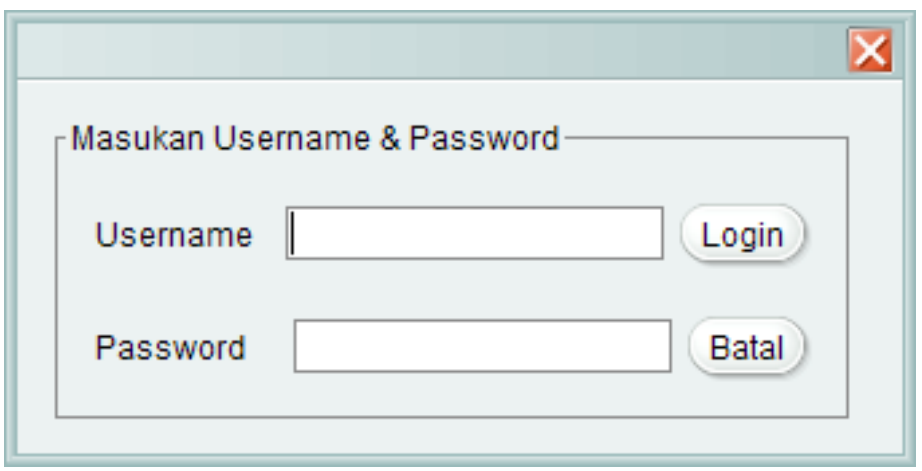

Gambar 4.4. Halaman Login

Jika login telah berhasil maka muncul notifikasi bahwa Admin telah berhasil masuk, seperti pada Gambar 4.5.

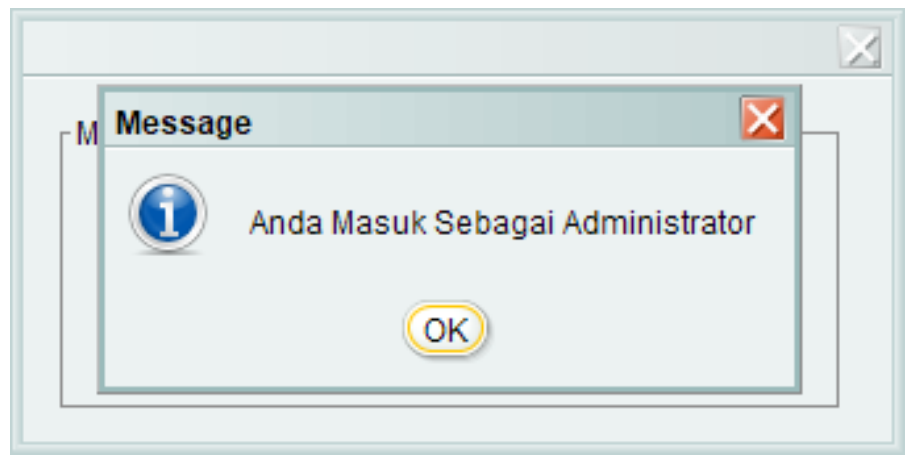

Gambar 4.5. Halaman Login Berhasil

Setelah login berhasil maka akan muncul kembali ke halaman utama dengan tiap tombol telah aktif atau dapat diakses, seperti pada Gambar 4.6.

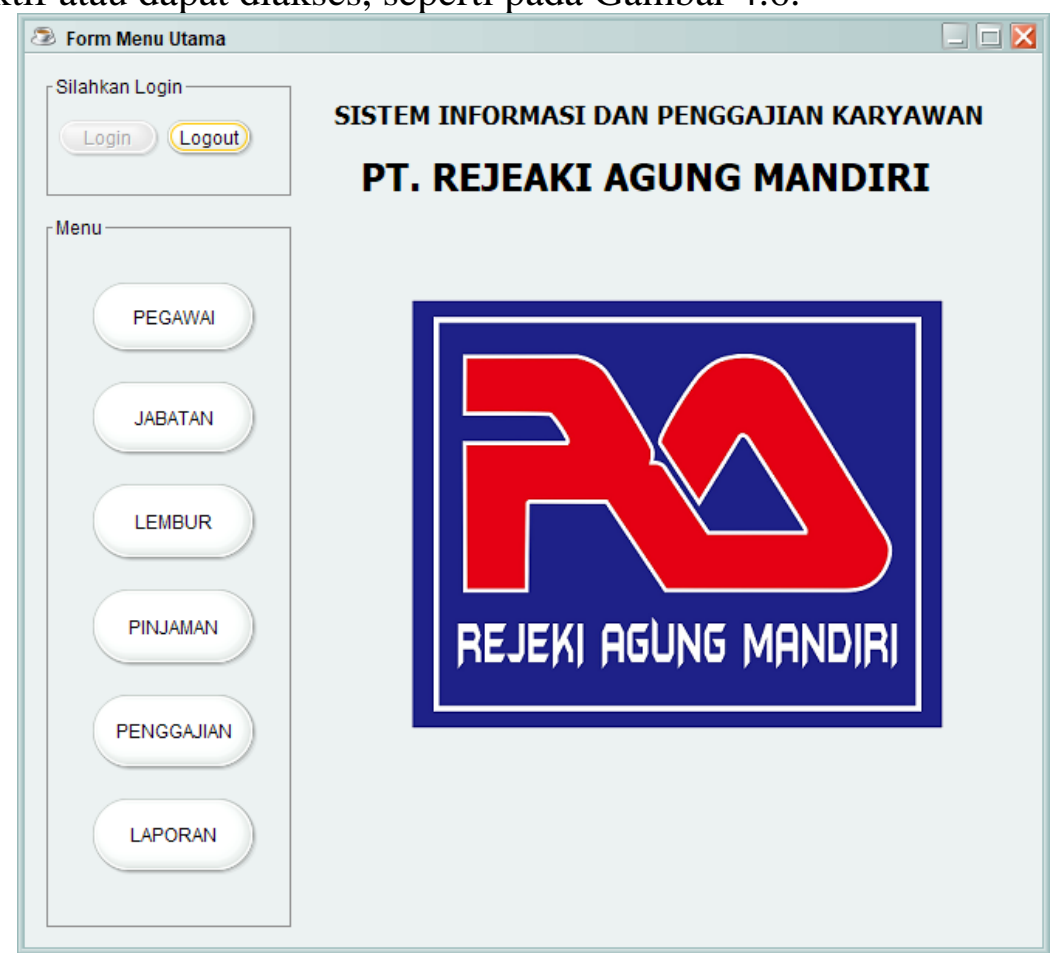

Gambar 4.6. Halaman Utama Sistem Aplikasi yang sudah aktif

3. Halaman Karyawan

Selanjutnya buka halaman karyawan, tekan tombol menu karyawan pada halaman utama tersebut. Pada halaman karyawan berisi tabel dari data karyawan yang telah diinputkan ke dalam tabel di dalam database. Untuk menginput data karyawan 


\section{Buletin Ekonomi}

terdapat form untuk menambah, mengedit atau menghapus data karyawan, dengan mencari data berdasar nama, ID karyawan, dan nomor identitas. Namun hanya admin yang dapat mengakses halaman ini. Tampilan dapat dilihat pada Gambar 4.7.

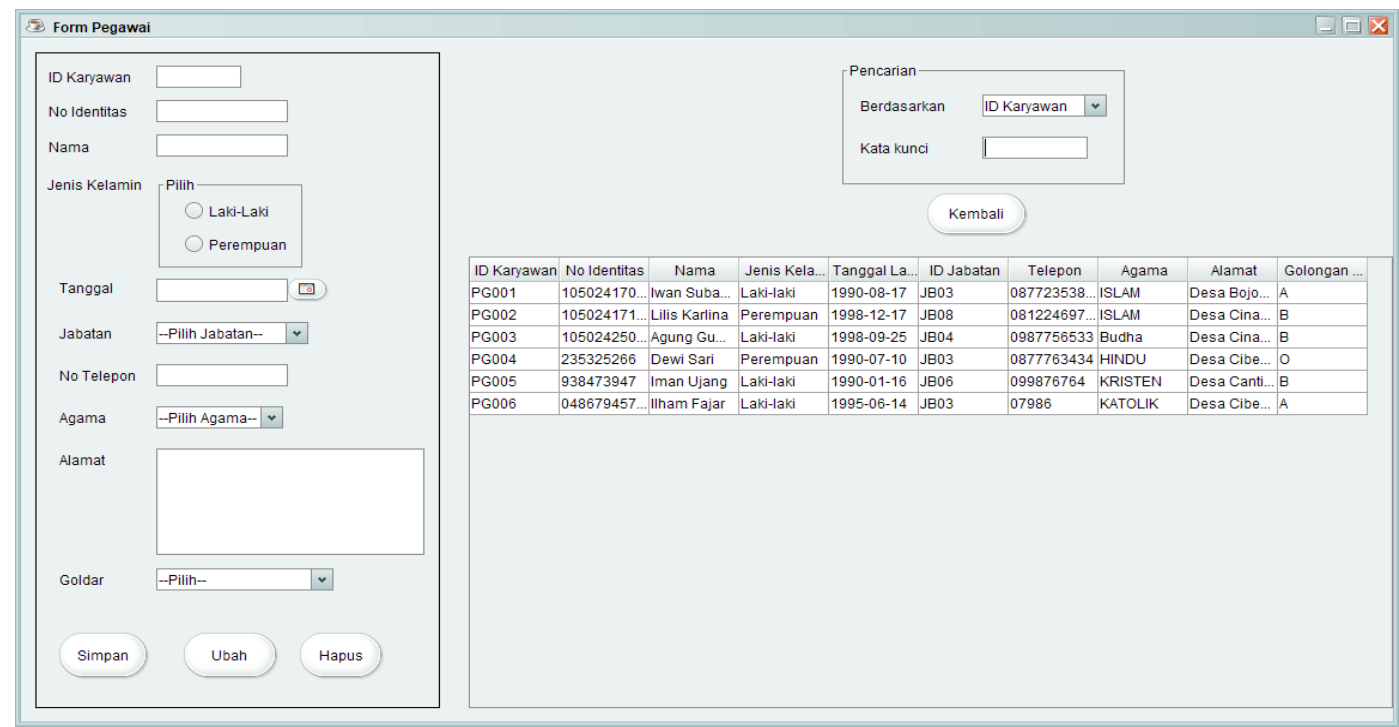

4. Halaman Jabatan

Gambar 4.7. Halaman Karyawaan

Tekan tombol menu jabatan untuk mengelola data jabatan. Data yang ditampilkan pada menu ini adalah ID jabatan, jabatan, gaji pokok, tunjangan uang makan dan tunjangan uang lembur. Di dalamnya juga terdapat form untuk melakukan penambahan, pengubahan, atau penghapusan data jabatan. Halaman ini hanya bisa diakses oleh admin. Halaman jabatan dapat dilihat pada Gambar 4.8.

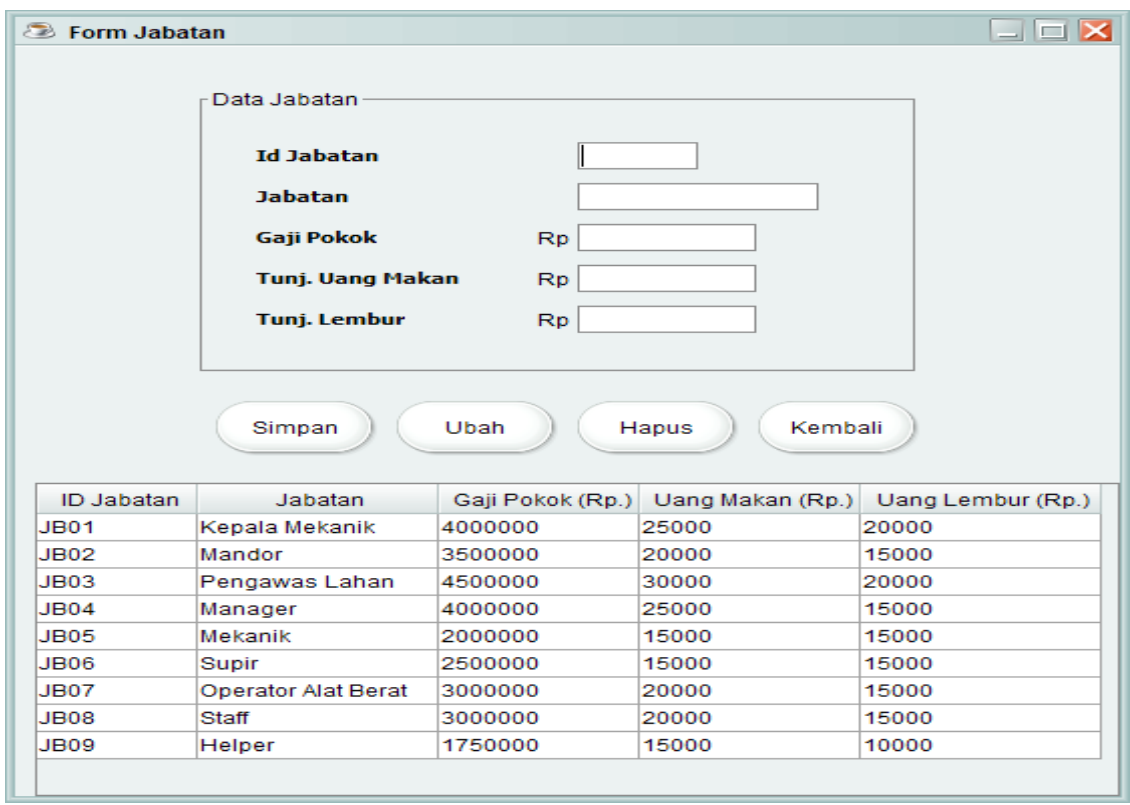

Gambar 4.8. Halaman Jabatan

5. Halaman Lembur

Setelah itu, klik tombol lembur dihalaman utama untuk mendata setiap kegiatan lembur karyawan. Pada halaman ini telah tersedia inputan data. Untuk menginput nama dan ID karyawan diharuskan mencari data karyawan yang telah 


\section{Buletin Ekonomi}

melakukan lembur. Setelah memilih karyawan, input tanggal, jumlah jam lembur dan keterangan lembur. Halaman lembur dapat dilihat pada Gambar 4.9.

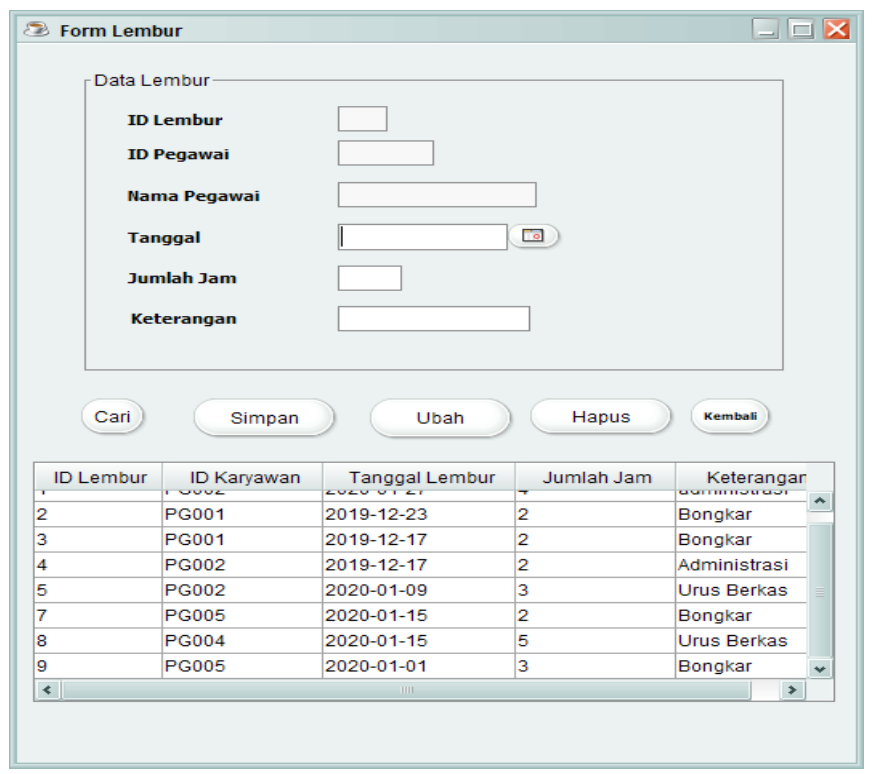

6. Halaman Pinjam

\section{Gambar 4.9. Halaman Lembur}

Selanjutnya klik tombol pinjam yang ada pada halaman utama untuk mendata setiap kegiatan pinjaman karyawan. Pada halaman pinjam telah tersedia inputan data. Untuk menginput nama dan ID karyawan terlebih dulu diharuskan mencari data karyawan yang telah melakukan pinjaman. Setelah memilih karyawan, admin harus menginput tanggal, jumlah pinjaman, dan keterangan pinjaman. Halaman pinjaman dapat dilihat pada Gambar 4.10.

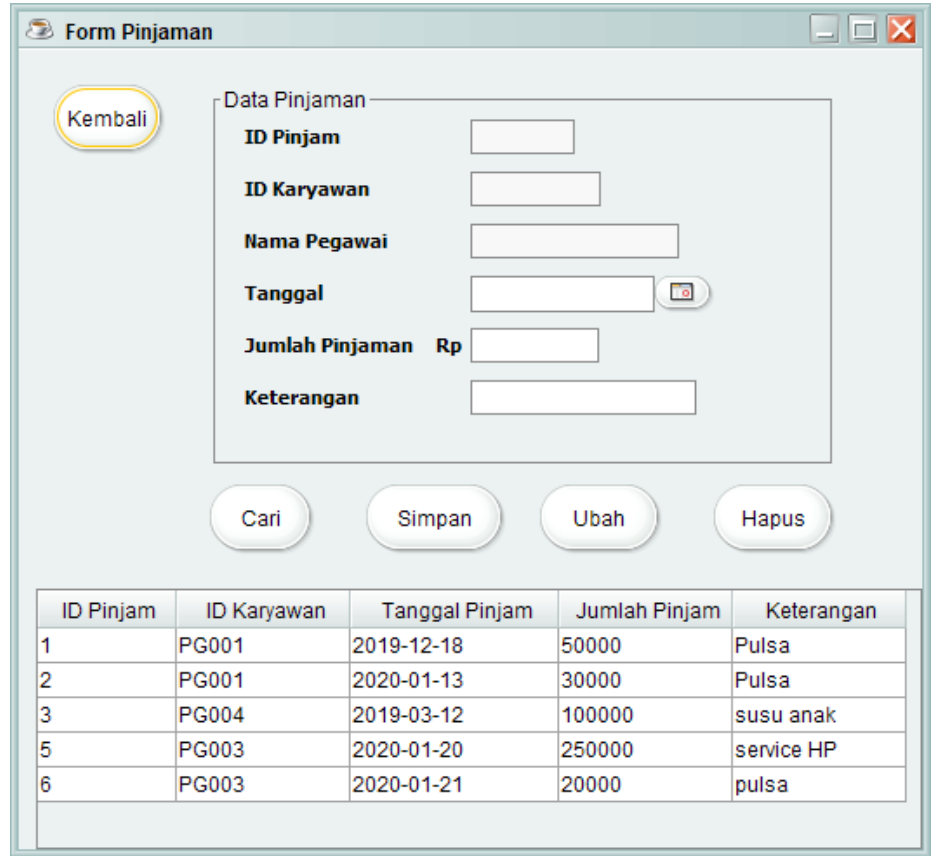

Gambar 4.10. Halaman Pinjaman 


\section{Buletin Ekonomi}

7. Halaman Penggajian

Dalam proses penggajian karyawan tekan tombol penggajian yang ada pada menu utama. Halaman pengggajian dapat dilihat pada Gambar 4.11.

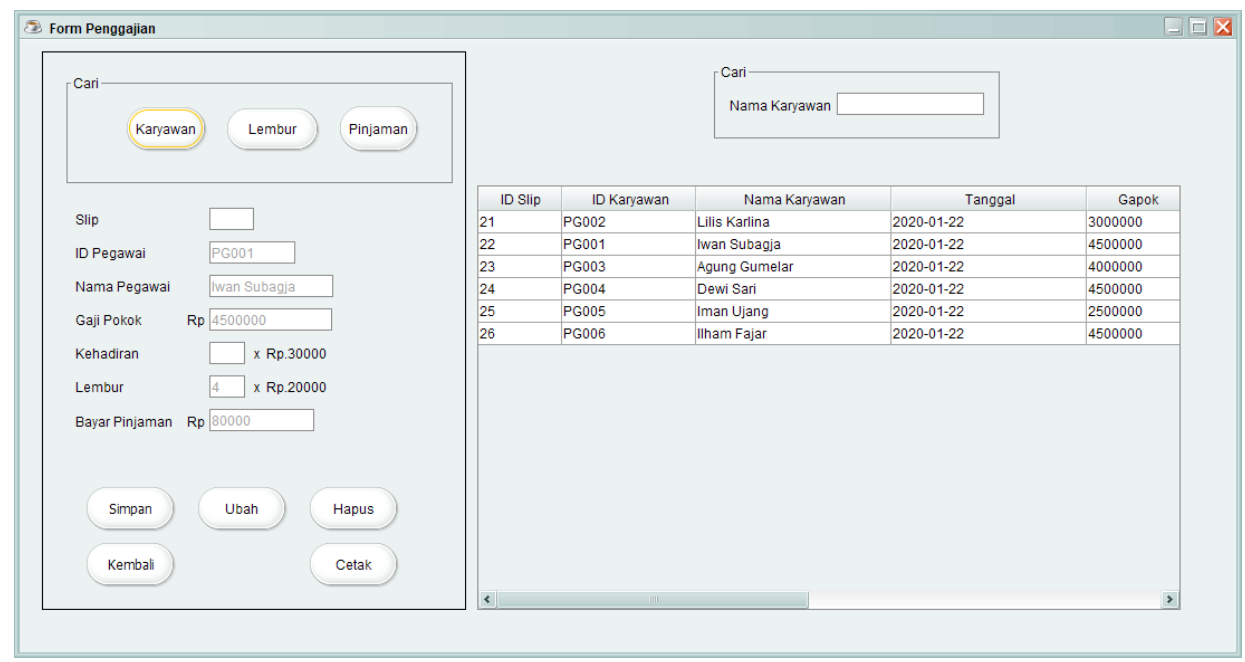

Gambar 4.11. Halaman Proses Penggajian

Selanjutnya, pilih karyawan yang akan dilakukan proses penggajian, dengan menekan tombol karyawan dan memilih karyawan yang terdaftar, seperti terlihat pada Gambar 4.12.

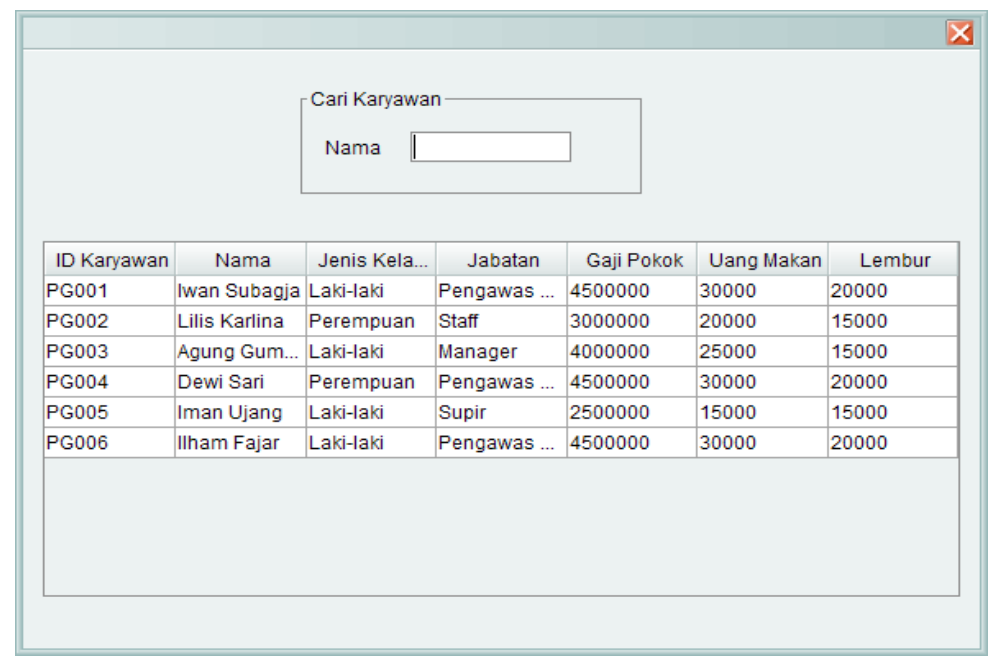

Gambar 4.12. Halaman Memilih Karyawan

Setelah memilih karyawan, selanjutnya mencari data lembur karyawan yang dipilih dengan menekan tombol lembur, seperti terlihat pada Gambar 4.13. 


\section{Buletin Ekonomi}

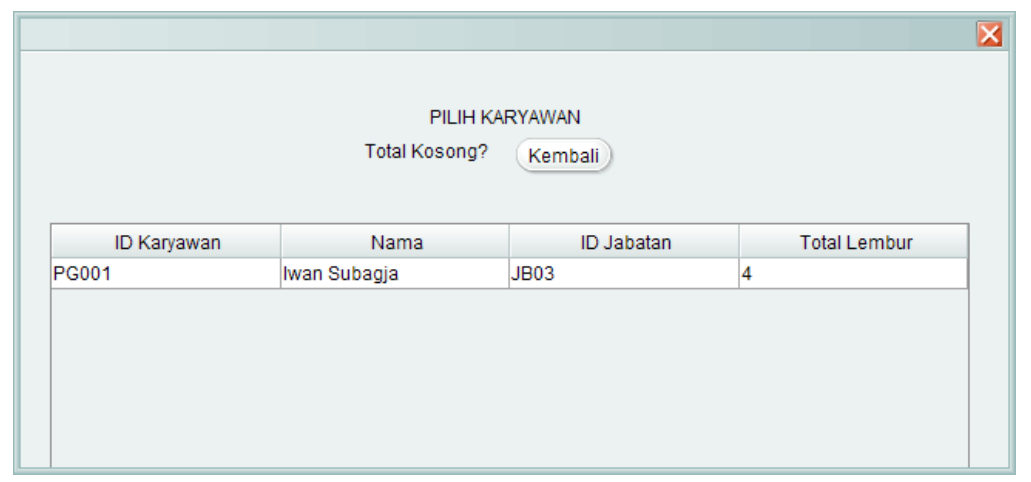

Gambar 4.13. Halaman Mencari Data Lembur Karyawan

Setelah memilih data lembur, selanjutnya mencari data pinjaman karyawan yang dipilih dengan menekan tombol pinjaman, seperti terlihat pada Gambar 4.14.

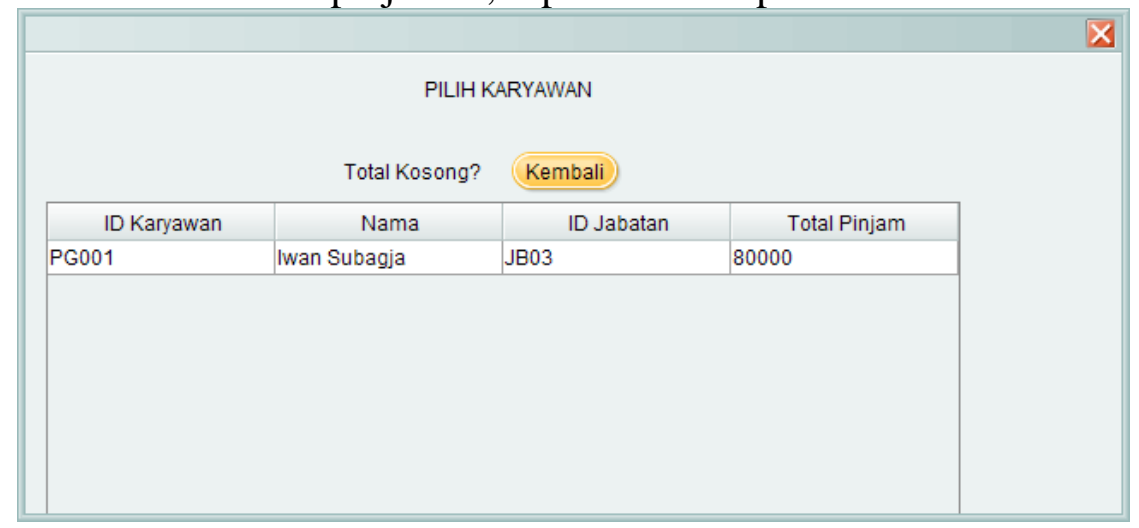

Gambar 4.14. Halaman Mencari Data Pinjaman Karyawan

Setelah melakukan semua proses dalam memilih karyawan, mencari data lembur, dan mencari data pinjaman karyawan, maka proses penggajian telah selesai. Proses penggajian akan menghasilkan slip gaji serta laporan - laporan data yang terkait lainnya.

Kelebihan dan Kelemahan yang ada dalam Sistem Penggajian

Kelebihan

Sistem yang digunakan pada PT. Rejeki Agung Mandiri sebelumnya menggunakan sistem manual. Sistem tersebut tidak terlalu banyak memerlukan data dan dokumen dalam proses penggajian. Namun, menggunakan sistem manual memerlukan waktu yang cukup lama dan rentan terjadi kesalahan, bila dibandingkan dengan sistem yang berjalan saat ini di PT. Rejeki Agung Mandiri yaitu sistem aplikasi NetBeans IDE 8.0.2 berbasis SQL Server. Sistem yang dirancang dengan tampilan pengguna yang sederhana dan tidak rumit akan lebih memudahkan penguna dalam mengoperasikannya. Sistem tersebut juga tidak memerlukan komputer berspesifikasi tinggi untuk menjalankannya dan tidak memerlukan waktu yang lama dalam proses penggajian. Hasil dari proses penggajian diharapkan menjadi lebih jelas dan akurat. Sistem ini juga dapat mengakomodasi transaksi berupa perhitungan gaji karyawan dan pinjaman. Sistem ini memiliki hak akses yang berbeda antara admin dan staff keuangan sehingga admin dapat memantau kinerja pegawai.

\section{Kelemahan}

Dalam sistem manual sangat rentan terjadi kesalahan dalam perhitungan dan memakan waktu yang lama sehingga yang dihasilkan dalam proses penggajian belum tentu jelas dan akurat. Namun, meskipun telah mengubah sistem manual menjadi menggunakan sistem berbasis desktop, belum tentu sistem tersebut sempurna karena masih memiliki beberapa kelemahan yaitu sistem berbasis database tidak dapat menampung jumlah data dalam jumlah 


\section{Buletin Ekonomi}

besar (big data). Dalam basis data yang digunakan masih mengandalkan storage pada komputer sehingga sangat rawan akan terjadinya lost data ketika komputer mengalami masalah. Sistem berbasis desktop juga belum mendukung client server dan masih begitu banyak bug yang ditemukan terkait dengan kesalahan logika. Serta dalam pemindahan data belum dapat dilakukan secara fleksibel, sehingga masih mengandalkan query.

\section{KESIMPULAN DAN SARAN}

Kesimpulan

Berdasar keseluruhan pembahasan yang telah diuraikan oleh penulis mengenai sistem penggajian pada PT. Rejeki Agung Mandiri, dapat ditarik beberapa kesimpulan dalam proses sistem penggajian pada perusahaan tersebut sebagai berikut:

1. Proses penggajian menggunakan sistem manual membutuhkan waktu yang lama dan rentan terjadi kesalahan perhitungan, sedangkan dengan menggunakan sistem yang berjalan saat ini yaitu sistem berbasis dekstop lebih efisien, cepat, dan akurat dalam proses maupun hasilnya.

2. Sistem yang diterapkan pada PT. Rejeki Agung Mandiri tersebut telah mencakup pendataan karyawan dan jabatan. Dalam proses penggajiannya, data lembur dan data pinjaman memiliki peran penting dalam perhitungan gaji bersih karyawan.

3. Sistem aplikasi NetBeans IDE 8.0.2 berbasis $S Q L$ server ini mudah digunakan karena dirancang dengan tampilan pengguna yang sederhana dan tidak rumit untuk proses penggajian, pendataan karyawan, serta pinjaman. Apabila terjadi kesalahan maka proses pengeditan dapat dilakukan dengan lebih mudah serta cepat dalam proses perbaikannya.

Saran

Adapun beberapa saran yang dapat penulis sampaikan untuk perusahaan bagi pola pengembangan sistemnya yang diterapkan yaitu sebagai berikut:

1. Sistem yang berjalan saat ini diketahui memiliki hambatan berupa tidak adanya fasilitas backup data, backup data dapat digunakan untuk mengembalikan data apabila terjadi kehilangan ataupun kerusakan pada data. Oleh karena itu, sistem tersebut pada PT. Rejeki Agung Mandiri dapat dikembangkan dengan menambahkan fasilitas backup data.

2. Sistem aplikasi NetBeans IDE 8.0.2 berbasis SQL server tersebut sebaiknya dilakukan pembaruan atau update secara berkala sesuai dengan kebijakan perusahaan.

3. Untuk pengembangan perusahaan ke arah yang lebih baik ke depannya, sebaiknya PT. Rejeki Agung Mandiri selalu mengikuti perkembangan teknologi aplikasi khususnya dalam dunia informasi keuangan...

\section{DAFTAR PUSTAKA}

A.Black, James Dan Dean Jean J. Champion. 2001, Metode Dan Masalah Penelitian Sosial. Terjemahan Oleh E. Koswara Dkk, Bandung: Reefika Aditama.

Agustina, Lydia, Alifia Oktrina Fayardi Dan Irwansyah (2018) Online Review: Indikator penilaian kredibilitas Online dalam Platform E-Commerce, Jurnal ilmu komunikasi Volume15,No2. 


\section{Buletin Ekonomi}

Guru, R. (2018). Pengertian Struktur Organisasi beserta Fungsi-Lengkap. https://www.ruangguru.co.id/pengertian-struktur-organisasi-beserta-fungsinya-secarajelas-dan-lengkap/.

Hery (2002). Pengantar Akuntansi 2. Jakarta: Erlangga.

Krismiaji (2015). Sistem Informasi Akuntansi. Yogyakarta: STIM YKPN.

Kusrini, \& Koniyo, A. (2007). Tuntunan Praktis Membangun Sistem Informasi Akuntansi dengan Visual Basis dan Microsoft SQL Server. Yogyakarta: C.V Andi Offset.

Romney, M. B., \& Steinbart, P. J. (2017). Sistem Informasi Akuntansi. Jakarta Selatan: Salemba Empat.

Sugiarso (2005). Dasar-Dasar Akuntansi Perkantoran. Yogyakarta: Media Pressindo. 